Atmos. Meas. Tech. Discuss., 3, 3643-3673, 2010

www.atmos-meas-tech-discuss.net/3/3643/2010/

Atmospheric

doi:10.5194/amtd-3-3643-2010

(c) Author(s) 2010. CC Attribution 3.0 License.

DWD ceilometer network

\title{
Aerosol profiling using the ceilometer network of the German Meteorological Service
}

\section{H. Flentje ${ }^{1}$, B. Heese ${ }^{2}$, J. Reichardt ${ }^{3}$, and W. Thomas ${ }^{1}$}

${ }^{1}$ Deutscher Wetterdienst, Meteorologisches Observatorium Hohenpeissenberg, Albin-Schwaiger-Weg 10, 82383 Hohenpeissenberg, Germany

${ }^{2}$ Institut für Troposphärenforschung, Permoserstr. 15, 03411 Leipzig, Germany

${ }^{3}$ Deutscher Wetterdienst, Meteorologisches Observatorium Lindenberg, 15848 Tauche, OT Lindenberg, Am Observatorium 12, Germany

Received: 14 June 2010 - Accepted: 11 August 2010 - Published: 23 August 2010

Correspondence to: H. Flentje (harald.flentje@dwd.de)

Published by Copernicus Publications on behalf of the European Geosciences Union.
Title Page

\section{Abstract}

Introduction

Conclusions

References

Tables

Figures

14

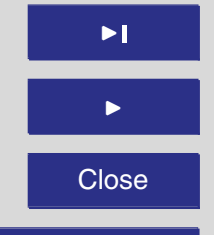

Full Screen / Esc

Printer-friendly Version

Interactive Discussion 


\section{Abstract}

The German Meteorological Service (DWD) operates about 52 lidar ceilometers within its synoptic observations network, covering Germany. These affordable low-power lidar systems provide spatially and temporally high resolved aerosol backscatter profiles 5 which can operationally provide quasi 3-D distributions of particle backscatter intensity. Intentionally designed for cloud height detection, recent significant improvements allow following the development of the boundary layer and to detect denser particle plumes in the free tropospere like volcanic ash, Saharan dust or fire smoke. Thus the network builds a powerful aerosol plume alerting and tracking system. If auxiliary aerosol information is available, the particle backscatter coefficient, the extinction coefficient and even particle mass concentrations may be estimated, with however large uncertainties. Therefore, large synergistic benefit is achieved if the ceilometers are linked to existing lidar networks like EARLINET or integrated into WMO's envisioined Global Aerosol Lidar Observation Network GALION. To this end, we demonstrate the potenepisodes over Europe, namely Sahara dust, Mediterranean fire smoke and, more detailed, the Icelandic Eyjafjoll volcano eruption from mid April 2010 onwards. The DWD (Jenoptik CHM15k) lidar ceilometer network tracked the Eyjafjoll ash layers over Germany and roughly estimated peak extinction coefficients and mass concentrations on 2017 April of $4-6( \pm 2) 10^{-4} \mathrm{~m}^{-1}$ and $500-750( \pm 300) \mu \mathrm{g} / \mathrm{m}^{-3}$, respectively, based on colocated aerosol optical depth, nephelometer (scattering coefficient) and particle mass concentration measurements. Though large, the uncertainties are small enough to let the network suit for example as aviation advisory tool, indicating whether the legal flight ban threshold of presently $2 \mathrm{mg} / \mathrm{m}^{3}$ is imminent to be exceeded.
AMTD

3, 3643-3673, 2010

DWD ceilometer network

H. Flentje et al.

Title Page

Abstract Introduction

Conclusions

References

Tables

Figures

I

14

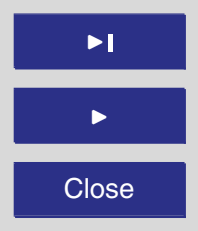

Back 


\section{Introduction}

Atmospheric particles modify the earth's radiation field (Hansen et al., 1997; Forster et al., 2007; Philipona et al., 2009), initiate the formation of clouds and precipitation (Kärcher, 2004; Andreae and Rosenfeld, 2008), mediate heterogeneous chemi5 cal reactions in the atmosphere and directly affect health through respiration or transmission of disease agents (Peters et al., 2005; Dockery et al., 2007). Thus their properties are monitored in situ at the surface (WMO - Global Atmosphere Watch GAW, US - AirNow, Asian-Dust-Net and others), by sondes or remotely by lidars and by optical sensors onboard satellites (CALIPSO/CLOUDSAT, MODIS/TERRA10 AQUA, SEVIRI/METEOSAT and others) on the long-term. Owing to the complexity of source, transformation and sink mechanisms, spatial and temporal inhomogeneities of particles are large compared to other atmospheric species, such that it is still competitious to capture all relevant parameters. Dust may disturb air-traffic through low visibility and in case of volcanic ash damage the coatings and front windows and even endanger jet-engines. Thus, building capabilities to monitor aerosols with high spatiotemporal resolution is a topical issue. In the planetary boundary layer $(\mathrm{PBL})$, the concerns deal with the dispersion of harmful pollution from accidents, fires or regular source regions or are in the context of EU-regulations with fine particle mass and threshold exceedance. A key element in understanding aerosolrelated processes and transport are vertical profiles of aerosol parameters that have been recorded since many years by lidar networks like EARLINET (Matthias et al., 2004; Böckman et al., 2004; Pappalardo et al., 2004) the Asian Dust Network (Murayama et al., 2001), NASA's Micro Pulse Lidar Network (MPLNET) or the Network for the Detection of Atmospheric Composition Change (NDACC), currently to be integrated into the overarching GALION initiative of the WMO (WMO, 2007), available at: http://www.wmo.int/pages/prog/arep/gaw/gaw-reports.html. These networks provide high-quality optical particle information, often wavelength- and polarisation-resolved, but they suffer from spatially sparse and temporally intermittent operation due to limited
AMTD

3, 3643-3673, 2010

DWD ceilometer network

H. Flentje et al.

\section{Title Page}

Abstract Introduction

Conclusions

References

Tables

Figures

14

14

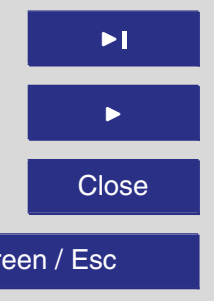

Printer-friendly Version

Interactive Discussion 
funding. To this end relatively low-power but also low-cost and low-maintenance lidar ceilometers can complement the networks' spatiotemporal density - though not at a grown-up lidar's accuracy. Ceilometers, intentionally designed for cloud base height detection, have been greatly improved over the last years and have shown their capability of monitoring the PBL (Menut et al., 1999; Davis et al., 2000; Münkel et al., 2007). Currently strong efforts are made to quantify the optical information derived from lidar ceilometers (Heese et al., 2010a,b; Frey et al., 2010). In this article we demonstrate the capabilities of the DWD ceilometer network for aerosol monitoring focussing on the case of the Eyjafjoll-volcano eruption in April 2010 and we investigate the informa10 tion content of state-of-the-art lidar ceilometer data operationally taken with a CHM15K system manufactured by the JENOPTIK LOS GmbH in Jena, Germany. We briefly discuss a comparison with data from the EARLINET lidar in Leipzig/Germany, and leave a more detailed analysis of the accuracy and uncertainties to later publications (Heese et al., 2010b; Wiegner, 2010). The data-set will also be used to evaluate meso-scale 15 model simulations in a follow-up paper by the EURAD group in Cologne. Here, we focus on the integration of the individual instruments to a Germany-wide aerosol monitoring network, the benefit through relation to EARLINET lidars, discuss the optical and micro-physical information content and conclude with an outlook to potential applications in numerical forecasting (Sect. 4). A summary is given in Sect. 5.

\section{The DWD ceilometer network}

As of mid-2008 the German Meteorological Service (DWD) equips a subset of its synoptic network stations with CHM15K lidar ceilometers, manufactured by JENOPTIK LOS GmbH in Jena, Germany (http://www.jenoptik.com/). In mid 2010, about 52 instruments are operational at the sites indicated in Fig. 1 from April 2010 (about 32 sites). At present the data arrive within weeks to months due to limited network capacities, but the network connections are currently upgraded for near real time availability.

\section{AMTD}

3, 3643-3673, 2010

\section{DWD ceilometer network}

H. Flentje et al.

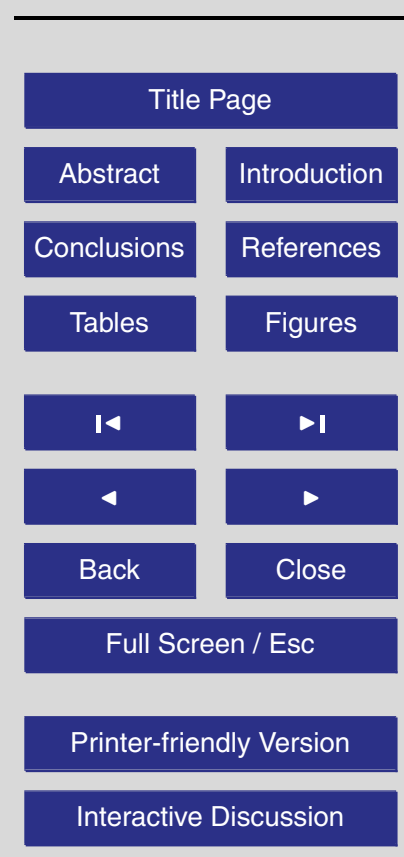




\subsection{The CHM15k lidar ceilometer}

The CHM15k uses a diode-pumped Nd:YAG solid state laser at the fundamental wavelength of $1064 \mathrm{~nm}$ yielding about $8 \mu \mathrm{J} /$ pulse at $5-7 \mathrm{kHz}$ repetition rate and $0.38 \mathrm{~nm}$ line width. The pulsed laser beam (divergence $100 \mu \mathrm{rad}$ - about 20 arcseconds) is emitted 5 off-axis of a $100 \mathrm{~mm}$ Newton-type receiving telescope with an aperture of $100 \mu \mathrm{rad}$. The telescope collects the back-scattered radiation through a narrow-band intereference filter onto an avalanche photodiode run in photon counting mode. The received signal is digitised by a $10 \mathrm{MHz} A D C$, resulting in a vertical resolution of $15 \mathrm{~m}$. The backscatter rawdata are offset-corrected, each profile devided by its standard deviation and then stored as netcdf files of about $12 \mathrm{MB} /$ day at $30 \mathrm{~s}$ resolution. Complete overlap of laser beam and telescope field of view is only reached around $1500 \mathrm{~m}$ above ground but the stability of the optical system allows correcting this effect down to about $600 \mathrm{~m}$. Improvements and issues related to an extension of the near-range applicability down to about $100 \mathrm{~m}$ a.g. with a newly developed fourfold-field-of-view optical system 15 is discussed in detail by (Frey et al., 2010).

\subsection{The CHM15k ceilometer data information content}

The CHM15k provides profiles of particle and molecular backscattering in an atmospheric column as described by the lidar equation. Solving the lidar equation for the backscatter coefficient profile is discussed in the lidar literature (Fernald, 1984; Klett,

1981, 1985; Matthias et al., 2004; Böckman et al., 2004; Pappalardo et al., 2004). It requires independent information on the backscatter-to-extinction ratio (lidar ratio (LR) profile) and on the backscatter coefficient at a reference height. As mostly no height resolved particle information is available, the LR is usually taken from corresponding closure studies (Mattis et al., 2004; Müller et al., 2007; Papayannis et al., 2008; Pappalardo et al., 2010) and regarded as height-independent. For optically thin aerosols this causes relatively small errors of the order of their optical thickness. Since we calibrate with AOD, the uncertainty of the extinction profile corresponds to that of the AOD
AMTD

3, 3643-3673, 2010

DWD ceilometer network

H. Flentje et al.

\section{Title Page}

Abstract Introduction

Conclusions

References

Tables

Figures

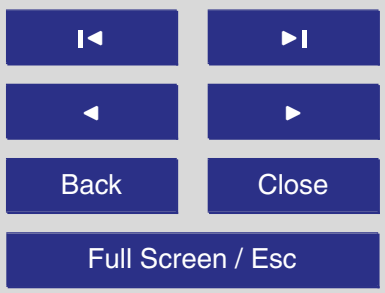

Printer-friendly Version

Interactive Discussion

(i) 
while the uncertainty of the LR transfers to the backscatter coefficient as the dependent variable. The wavelength $1064 \mathrm{~nm}$ provides relatively large contrast to molecular scattering, thus highlighting aerosol structures, but the scattering efficiency drops down sharply for particles with radii well below $1 \mu \mathrm{m}$ (v.d. Hulst, 1957). The Rayleigh 5 scattering signal (e.g. $\sigma_{e, R} \approx 8 \times 10^{-8} \mathrm{~m}^{-1} \mathrm{sr}^{-1}$ in $3 \mathrm{~km}$ ) is at the sensitivity limit of the ceilometers which limits single profile calibration by the molecular background signal in the free troposphere. While lidars with 1-2 orders of magnitude higher laser power may still receive molecular return from the upper troposphere, even at $1064 \mathrm{~nm}$, little molecular signal is received from beyond $3-5 \mathrm{~km}$ altitude by ceilometers (better dur10 ing night), depending on the PBL turbidity. However, co-located aerosol optical depth (AOD) and surface nephelometer measurements (for the overlap portion) may allow calibration even so. Typically, the PBL is the prominent feature of the backscatter sections, and different algorithms for PBL-height detection in ceilometer/lidar data may be applied (Münkel et al., 2007; Beyrich et al., 2010). Further, elevated aerosol layers are 15 frequently observed above the PBL. Several limitations apply for the DWD ceilometer network at present: Firstly, ceilometers do not resolve depolarisation to infer the particle asphericity respective their phase. Then, with only one wavelength it's not straightforward to distinguish thin cirrus clouds from high aerosol layers - which in addition may occasionally be associated with clouds. Sometimes webcams may help and the fact that clouds typically scatter much stronger than aerosols. Thus, in order to distinguish different particle types in the ceilometer profiles, auxiliary information is required, e.g. about particle origin from air mass analyses or complementary measurements. Operational ceilometer networks should therefore be integrated into lidar, AOD and in situ networks in order to interpolate the inferred particle type, optical and microphysical information to quasi 3-D distributions. Particles aloof the PBL typically originate from remote sources like Saharan dust, fire smoke and volcanic particle plumes. A ceilometer network can follow the dispersion of extended denser aerosol plumes during short notice events as discussed in Sect. 3. In order to proof the validity of backscatter profiles retrieved from the ceilometers, inter-comparisons with EARLINET reference lidar
AMTD

3, 3643-3673, 2010

DWD ceilometer network

H. Flentje et al.

\section{Title Page}

Abstract Introduction

Conclusions References

Tables Figures

14

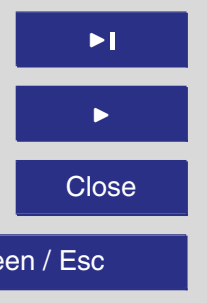

Full Screen / Esc

Printer-friendly Version

Interactive Discussion 
systems (Raman Lidar of the Institut für Troposphärenforschung (IfT) Leipzig/Germany and the Portable Lidar System POLIS of the Ludwig Maximilians-University (LMU) Munich/Germany have been analysed in detail by (Heese et al., 2010b; Wiegner, 2010), respectively. Both, the basic and the near overlap version of the $\mathrm{CHM} 15 \mathrm{~K}$ have been 5 used there, which have different day/night capabilities (background signal) due to different fields of view. In this article, we demonstrate that optical and micro-physical particle properties may be estimated from ceilometer profiles and co-located AOD observations on short notice with an accuracy sufficient for online aerosol plume alerting. We also demonstrate the limitations in observing thin aerosol layers by comparing ceilometer to 10 lidar profiles.

\section{Observations - case studies}

\subsection{Volcanic ash - Eyjafjoll eruption in April 2010}

Volcanic ash injected into the stratosphere can unlikely be identified by CHM15k ceilometers because the layers are largely homogeneous (lacking internal structure) 15 and the backscatter signal received from these altitudes is low. Even Pinatubo strength eruptions only produce backscatter coefficients around $10^{-7} \mathrm{~m}^{-1} \mathrm{sr}^{-1}$ (Jäger and Hoffmann, 1991). This can be different for tropospheric ash clouds. The eruption of the Icelandic Eyjafjoll volcano as of 14 April 2010, massively injected particles into the troposphere up to about $10 \mathrm{~km}$ altitude. The ash plume crossed Germany from north (16 April, 00:00-12:00 UT) to south (17 April, 00:00-15:00 UT), was deflected towards west and east at the Alps and resided over Central Europe for several days thereafter. Chemistry/aerosol transport models (e.g. http://www.metoffice.gov.uk/aviation/ vaac/ or http://www.eurad.uni-koeln.de/) and Lagrangian codes (e.g. HYSPLIT, FLEXPART) predicted the dispersion of the ash plume but suffered from unknown emission strengths and injection heights. At a first view though, these simulations qualitatively reproduced the dispersion of the main ash cloud reasonably well. Initially
AMTD

3, 3643-3673, 2010

DWD ceilometer network

H. Flentje et al.

\section{Title Page}

Abstract Introduction

Conclusions

References

Tables Figures

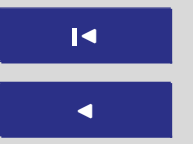

$\Delta$

Back $\triangleright$

Full Screen / Esc

Printer-friendly Version

Interactive Discussion 
real time tracking of the ash and evaluation of the model forecasts was performed by sparse ozone-sondes, few lidars and several ceilometers distributed over Europe, amongst them about $25 \mathrm{CHM15k}$ laser-ceilometers from the DWD network (Flentje et al., 2010a). At the north-easterly edge of an extended Azores High (Fig. 3) the 5 plume reached Northern Germany in 2-6 km altitude (Fig. 1) and subsided by $1-2 \mathrm{~km}$ (according to ECMWF vertical wind analyses) on it's way south, thereby forming a dense roughly $1 \mathrm{~km}$ thick layer with largely enhanced particle concentration. As indicated by a CALIOP snapshot over Belgium on 16 April (available on their web-site), the western part of the layer was strongly tilted, which contributed annother $1-2 \mathrm{~km}$ of 10 apparent descent at the ceilometer locations over the day. At the middle and southern German stations the front of the ash layer arrived in about 6-7 km height, then gradually descended (in time) and concentrated after several hours around $2-4 \mathrm{~km}$ altitude (Fig. 2). In the corresponding figures this appears as a down-tilting orange-coloured layer. The seemly intermittence of the layer at several stations is due to low clouds 15 which temporarily shadowed the ash above. On 17 April the ash layer was then only observed over the southern parts of Germany where it was entrained into the convective PBL from noon onwards (Fig. 4). Simultaneous increases of the $\mathrm{SO}_{2}$ and $\mathrm{H}_{2} \mathrm{SO}_{4}$ concentrations as well as the number concentration of large particles $(d \approx 1-4 \mu \mathrm{m})$ at the Global Atmosphere Watch observation sites Hohenpeissenberg and Schneefernerhaus (Zugspitze) confirmed the volcanic origin (Flentje et al., 2010b). Part of the airmass moved toward France, returned on 19/20 April and diminished slowly during the next days. Then this first Central European ash episode was interrupted by changing transport patterns over the northern Atlantic. Thin ash layers were observed over Germany till 25 April when the laborious by-hand $\mathrm{CHM} 15 \mathrm{k}$ data collection was interrupted 25 for the time being. At Hohenpeissenberg thin layers on 18 April (00:30 UT) and 19 $(15: 30 \cup T$, AOD $\tau \approx 0.15)$ only reached peak backscatter ratios around $1 \times 10^{-6} \mathrm{~m}^{-1} \mathrm{sr}^{-1}$ and $2 \times 10^{-7} \mathrm{~m}^{-1} \mathrm{sr}^{-1}$, respectively $(\mathrm{LR}=50)$. Compared to a high power lidar, the ceilometers' capabilities are, however, limited as may be demonstrated by the POLIS (354 nm) lidar at LMU Munich, available at: http://www.meteo.physik.uni-muenchen.de/
AMTD

3, 3643-3673, 2010

DWD ceilometer network

H. Flentje et al.

\section{Title Page}

Abstract Introduction

Conclusions References

Tables Figures

$1<$

4

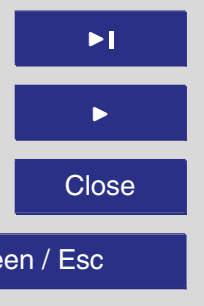

Full Screen / Esc

Printer-friendly Version

Interactive Discussion 
stlidar/quicklooks/mim_quicklooks.html, which shows the 19 April layer compact near $4 \mathrm{~km}$ where it needs a close look to reveal this layer in the ceilometer data. Similarly, the remnants of the ash over Leipzig on 19 April (Fig. 5) shows up as one noisy weak layer around $4-5.5 \mathrm{~km}$ in the ceilometer while the corresponding plot of the MARTHA 5 lidar at IfT Leipzig, e.g. available at: http://polly.tropos.de/martha/quicklook.php?year= $2010 \backslash \&$ month $=4 \backslash \&$ day $=19 \backslash \&$ plot $=1$ still reveals several layers with internal structure (the densest one seen by the CHM15k) reaching up to $9 \mathrm{~km}$ altitude.

\subsection{Saharan dust}

Saharan dust is transported to Central Europe about 5-15 times per year but does not always penetrate down to the ground. It contributes significantly to annual average $\mathrm{PM}_{10}$ levels and may even be dominant in the countries enclosing the Sahara desert. Since European threshold exceedance legislations apply, identification of Saharan dust and its cross boundary transport is a political issue. Dust plumes are relatively easy to identify with aid of trajectories and satellite images (e.g. AQUA/MODIS) or operational forecasts (e.g. ECMWF-MACC, http://www.gmes-atmosphere.eu). The transport of dust plumes and their vertical re-distibution can be tracked by the ceilometer network as illustrated with the time series at Lindenberg, Germany $\left(53.2^{\circ} \mathrm{N}, 14.2^{\circ} \mathrm{E}\right)$ for the period 24 May-3 June 2008. Figure 6 shows the transport pattern of Sahara dust to Central Europe in the GEMS AOD forecast for 29 May 2008. The time-heightsection of particle backscatter (Fig. 7) reflects the layering and temporal development of the dust layer above Lindenberg. Thereby the settling is due to large scale subsidence rather than particle sedimentation which is of the order of several $10 \mathrm{~m}$ per day only for sizes of a few $\mu \mathrm{m}$. Calibration of the profiles by AOD measured in Lindenberg ( $\tau \approx 0.22 \pm 0.04$ on 29 May, 07:30-08:30 UTC) yields maximum extinction coeffi25 cients about $\sigma_{e} \approx 2-3( \pm 1) \times 10^{-4} \mathrm{~m}^{-1}$. On 30 May, AOD ranging from $\tau \approx 0.25 \pm 0.03-$ $0.35 \pm 0.03$ even yield extinction coefficients in the range of $\sigma_{e} \approx 6( \pm 2) \times 10^{-5} \mathrm{~m}^{-1}$ $6( \pm 2) \times 10^{-4} \mathrm{~m}^{-1}$. Analogue to the discussion for volcanic ash in Sect. 4, we will in
AMTD

3, 3643-3673, 2010

DWD ceilometer network

H. Flentje et al.

\section{Title Page}

Abstract Introduction

Conclusions

References

Tables

Figures

I

14

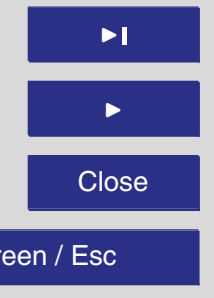

Printer-friendly Version

Interactive Discussion 
future compare ceilometer and $\mathrm{PM}_{10}$ measurements from Hohenpeissenberg to verify/expand literature values for the specific extinction coefficient (or mass extinction efficiency) e.g. given by (Gerasopoulos et al., 2009; Lacis and Mishchenko, 1994).

\subsection{Fire smoke - Mediterranean fires in summer 2009}

5 Wildfires are large sources of reactive trace gases and particles in the atmosphere (Goode et al., 2000; Andreae and Merlet, 2001) impacting not only the atmospheric oxidation capacity via the $\mathrm{CO}$ and $\mathrm{O}_{3}$ background concentrations, but also air quality over even long distances. Again, ceilometer or lidar networks are a suitable tool to track regional and global scale transport of fire plumes, for verifying injection heights in particle dispersion models and estimations of the particles' optical and micro-physical properties (Wandinger et al., 2002). As an example, thin layers of forest fire smoke were observed by the DWD ceilometer network in August 2009, when wildfires occurred over parts of the Mediterranean countries Spain, Southern France, Corse and Greek. On 23 August, shallow smoke layers moved south-easterly over Germany, thereby subsiding in the anticyclonic flow from altitudes up to $5 \mathrm{~km}$ in the west to roughly $3 \mathrm{~km}$ in the SE (Fig. 8). Back trajectories trace the smoke plume back to the Western Mediterranean (Fig. 9). Fire smoke typically forms such thin layers in the free troposphere because it is injected into a narrow altitude range depending on the strength of the pyroconvection and it spreads out nearly isentropically under stable anticyconlic conditions. The poor knowledge of the injection height along with vertical wind shear, however, impedes large uncertainties on the calculated 3-D trajectory. An analysis of the optical properties of the descending smoke layer at Hohenpeissenberg yields peak backscatter coefficients of $\beta \approx 2( \pm 1) \times 10^{-7} \mathrm{sr}^{-1} \mathrm{~m}^{-1}$ with an uncertainty imposed by the AOD-extinction calibration and the LR-dependent extinction-to-backscatter conversion

of more than $50 \%$. Note that due to calibration via AOD the extinction here can be quantified more precise than the inferred backscatter coefficient. As smoke particles typically are small $(\mathrm{d} \approx 0.1-0.3 \mu \mathrm{m} \ll 1.064 \mu \mathrm{m})$ their LR varies stronger than for large ones, typical values range from 40 to $80 \mathrm{sr}$ at $532 \mathrm{~nm}$ (Wandinger et al., 2002), being

\section{AMTD}

3, 3643-3673, 2010

\section{DWD ceilometer} network

H. Flentje et al.

\section{Title Page}

Abstract Introduction

Conclusions

References

Tables

Figures

1

14

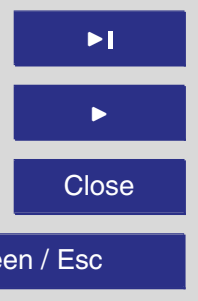

Printer-friendly Version

Interactive Discussion

\section{Full Screen / Esc}


smaller at $1064 \mathrm{~nm}$. Therefore, an estimation of extinction and mass concentrations comprises much larger errors than for coarse particles. The smoke layers have also been observed by EARLINET lidars e.g. by IfT Leipzig and LMU Munich. Corresponding range-corrected signal plots are available on their websites given above.

\section{Discussion - integration and application}

\subsection{Calibration by co-located AOD and nephelometer measurements}

Absolute calibration of the profiles requires either pure Rayleigh scattering at a reference point or, in case of significant particle scattering throughout the profile, knowledge of the backscatter ratio $\gamma=\beta_{\text {part }} /\left(\beta_{\text {part }}+\beta_{\text {mol }}\right)$, i.e. the contribution of particle scatter10 ing to the total (molecular+particulate) scattering, somewhere in the profile. Since both are usually not available for standalone ceilometers operating at $1064 \mathrm{~nm}$, colocated radiometer (AOD) and nephelometer (scattering coefficient) data may be applied in order to calibrate the ceilometer profiles, provided that the sky is cloud free and that the PBL is sufficiently homogeneous such that comparable air-masses are observed. Both the LR and the reference value may then be iterated to fit the observed AOD, which means practically that the effective LR should be approximately known either from scattering calculations (Hess et al., 1998) or other sources. Normally the backscatter coefficient of optically thin aerosols is little sensitive to the LR, while the extinction profile scales directly. But if the backscatter profiles are calibrated "inversely" via AOD, it is the other way round. The missing overlap portion of the ceilometer's extinction integral may be estimated by means of a multi wavelength nephelometer (Doherty et al., 1999). This premises the negligibility of the near-surface aerosol gradient and may require the extrapolation to the employed wavelength by means of the Angstrom Exponent. While this be approximately fulfilled in a well mixed PBL, the limitations of (elastic) lidar signal inversion leave the ceilometer profiles at a qualitative level otherwise. Considering the Eyjafjoll ash layer observed at Hohenpeissenberg

\section{AMTD}

3, 3643-3673, 2010

\section{DWD ceilometer} network

H. Flentje et al.

\section{Title Page}

Abstract Introduction

Conclusions

References

Tables

Figures

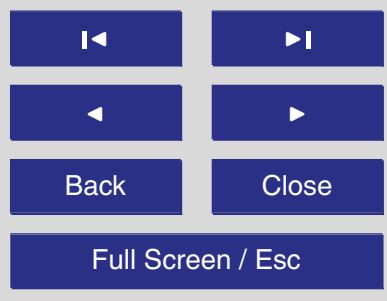

Printer-friendly Version

Interactive Discussion 
(Southern Germany) for example on 17 April, 08:30-09:30 UTC, the AOD at $1020 \mathrm{~nm}$, measured with a precision filter radiometer (PFR) and handheld MICROTOPS II radiometer, yielded $\tau \approx 0.23 \pm 0.03$. The scattering coefficient near the surface (TSI 3563 $3 \lambda$-nephelometer - extrapolated to $1064 \mathrm{~nm}$ by means of the Angstrom Exponent $\alpha$ $5\left(\sigma(\lambda)=\sigma\left(\lambda_{0}\right)\left(\lambda / \lambda_{0}\right)^{-\alpha}\right)$ was about $\sigma_{s, 1064 \mathrm{~nm}} \approx 6.3( \pm 2) \times 10^{-5} \mathrm{~m}^{-1}$ which integrates over the convective PBL to $\tau \approx 0.09( \pm 0.03)$. The remaining AOD of $\tau \approx 0.14( \pm 0.05)$ splits into the contributions of a shallow cleaner layer between the ash and the PBL, the ash layer itself and the troposphere above the layer, estimated in sum to $\tau \approx 0.03( \pm 0.02)$. Thus, the inversion of the cloud free backscatter profile yields an extinction coeffi10 cient of $\sigma_{e} \approx 4.6-5.2( \pm 2.3) \times 10^{-4} \mathrm{~m}^{-1}$ at $3 \mathrm{~km}$ a.s.l. to produce the extinction integral $\tau \approx 0.14( \pm 0.06)$ (Fig. 4). The uncertainty of the inferred extinction coefficient scales nearly linearly with the uncertainty in the AOD. Below the clean layer, the lowest part of the ceilometer extinction profile is affected by the incomplete laserbeam-telescopeoverlap and must be interpolated to the scattering coefficients measured at the surface.

15 This adds a hardly quantifyable uncertainty which depends on PBL homogeneity but is negligible in a well mixed convective PBL. An additional error of about $3 \%$ adds due to neglecting the contribution of absorption $\left(\sigma_{a} \approx 2 \times 10^{-6} \mathrm{~m}^{-1}\right)$ to the surface extinction coefficient, measured with a Particle Soot Absorption Photometer. In the next step, the prescribed LR $=50 \mathrm{sr}$ (Pappalardo et al., 2010) and the inferred backscatter calibration of the profile was applied to the whole day and the other network ceilometers, which indicates that the peak optical density of the ash layer only gradually decreased while crossing Germany. The LR likely remained constant for days since the ash particles (advected more or less passively) were larger than the laser wavelength $\left(r_{p} \approx 1-4 \mu \mathrm{m}\right)$ and their sizes at the Hohenpeissenberg station agreed with in situ measurements onboard the DLR Falcon on 19 April (Weinzierl, B., German Aerospace Centre (DLR), personal communication, 2010). 


\subsection{Validation by Raman Lidar measurement}

As an exemplary validation, we show night-time ceilometer backscatter profiles from the station Leipzig-Holzhausen/Germany and compare these to profiles from the Polly $^{X T}$ Raman lidar (Althausen et al., 2009), taken $2 \mathrm{~km}$ apart by the Lidar at the 5 Institute for Tropospheric Research (IfT) Leipzig/Germany (Fig. 10). For simplification, a constant lidar ratio of $55 \mathrm{sr}$ - valid for both urban particles and Saharan dust (Müller et al., 2007; Papayannis et al., 2008) - was used to derive the profiles from the ceilometer and the elastic signal of the Raman lidar. From the Raman Lidar the extinction profile can be derived without a-priori assumptions but the backscatter pro-

file needs also a reference value at a particle free layer (Ansmann et al., 1990). The ceilometer profile, taken on 15 April 2009 from 00:00-03:00 UTC (Fig. 10) shown in red compares well with the elastic backscatter profile at $1064 \mathrm{~nm}$ of Polly ${ }^{X T}$ shown in blue. At lower altitudes a double aerosol layer was observed by both the lidar and the ceilometer. This layer reaches up to $3 \mathrm{~km}$ height. The maximum values of the 5 ceilometer are slightly higher than the values from the lidar profiles. Above this layer low backscatter signals were observed up to about $5 \mathrm{~km}$ by both instruments before no aerosol signal is detected between 5 and $6.5 \mathrm{~km}$. From 6.5 to $11 \mathrm{~km}$ height, another distinct aerosol layer was detected. This layer likely contained Saharan dust as indicated by FLEXPART (Stohl et al., 1998) calculations (not shown) and supported by DREAM dust forecasts which show a dust layer at these altitudes (c.f. Barcelona Supercomputing Centre). This dust layer was present over Leipzig during the night and diminished during the following day. Its structure is well resolved by both the lidar and the ceilometer profiles, although the latter is already getting noisier at those altitudes. The signal-to-noise ratio is discussed in more detail by (Heese et al., 2010b). The AOD 25 derived from the ceilometer profile is $\tau=0.11$. To integrate the AOD from the ceilometer's extinction profile, the extinction values at the height range with incomplete overlap below $1 \mathrm{~km}$ were extrapolated as constant and set equal to the extinction value at $1 \mathrm{~km}$ height. The AOD value from the elastic lidar profile is derived in the same manner and
AMTD

3, 3643-3673, 2010

DWD ceilometer network

H. Flentje et al.

\section{Title Page}

Abstract Introduction

Conclusions

References

Tables Figures

14

14

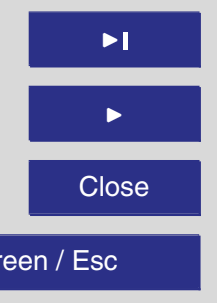

Full Screen / Esc

Printer-friendly Version

Interactive Discussion 
is $\tau=0.094$. The AOD derived from the Raman extinction profile is $\tau=0.097$. The independent measurement of the AOD by a sun photometer yields a value of $\tau=0.11$ at $1020 \mathrm{~nm}$. The good agreement between these values demonstrate the ability of the ceilometer to measure the vertical aerosol profile. Though the AOD from the ceilome5 ter is slightly closer to the sun photometers AOD, these small differences remain within the measurement errors.

\subsection{Empirical estimation of particle concentrations}

Severe aerosol episodes trigger enquiries for estimates of bulk particle properties, first of all the particle mass concentration. The necessary conversion of optical to 10 micro-physical particle properties, here the specific extinction coefficient $\sigma_{e}^{*}=\sigma_{e} / \mathrm{m}_{\text {part }}$, depends on the particle size, -density and -composition. It (or $\beta^{*}=\beta / \mathrm{m}_{\text {part }}$ ) has been reported for the stratosphere (Jäger and Hoffmann, 1991), for traffic (Rauth et al., 2009), for Saharan dust (Gerasopoulos et al., 2009) and satellite derived AOD (Wang and Christopher, 2003; Gupta et al., 2006). One may also calculate it from 15 global aerosol data sets e.g. (Hess et al., 1998) or estimate it from surface measurements. For the latter approach, $\sigma_{e}^{*}$ during the Eyjafjoll period is considered at the GAW station Hohenpeissenberg, where the ash was entrained into the PBL on 17 April 2010 and resided there till 20 April 2010 as indicated by surface $\mathrm{SO}_{2}$ measurements (Flentje et al., 2010b). Before the ash's entrainment a substantially different air mass prevailed, possibly mixed with some Saharan dust. The specific extinction decreased from initially $\sigma_{e, 1064 \mathrm{~nm}}^{*} \approx \sigma_{s, 1064 \mathrm{~nm}}^{*} \approx 1.6 \mathrm{~m}^{2} / \mathrm{g}$ before the ash was completely mixed into the PBL to about $0.8( \pm 0.1) \mathrm{m}^{2} / \mathrm{g}$ in its main body (Fig. 11). The range of these values is similar as for Saharan dust (Gerasopoulos et al., 2009) and corresponds reasonably to optical calculations (e.g. by Wiegner, M., Ludwig25 Maximilians University LMU, Munich/Germany, personal communication, 2010) and to values meanwhile reported for the Jungfraujoch GAW Station (ACP conference, Interlaken, June 2010). Based on these considerations, ceilometer profiles over different

\section{AMTD}

3, 3643-3673, 2010

\section{DWD ceilometer} network

H. Flentje et al.

\section{Title Page}

Abstract Introduction

Conclusions

References

Tables

Figures

14

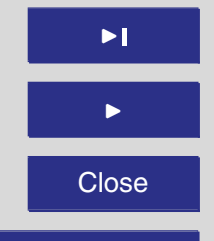

Full Screen / Esc

Printer-friendly Version

Interactive Discussion 
German stations with acceptable signal/noise ratio $(>2)$ were used to estimate the particle mass-concentration within the Eyjafjoll ash layers over Germany on 16/17 April. Assuming that the specific extinction obtained near the surface is representative for the PBL, the peak extinction coefficients within the subsiding ash-layer of $5 \sigma_{e, \text { estim }} \approx 4-6( \pm 2) \times 10^{-4} \mathrm{~m}^{-1}$ (Sect. 4.1) correspond to a mass concentration of the order of $500-750( \pm 300) \mu \mathrm{g} / \mathrm{m}^{3}$. Two days later on 19 April the extinction of the ash over Germany had decreased to $\sigma_{e \text {,estim }} \approx 3-5( \pm 1) \times 10^{-5} \mathrm{~m}^{-1}$ at $4-6 \mathrm{~km}$ altitude, corresponding to mass concentrations of $30-50( \pm 20) \mu \mathrm{g} / \mathrm{m}^{3}$. The magnitude of these estimates are confirmed by EARLINET lidar (Ansmann et al., 2010; Wiegner, M., LMU

Munich, Germany) and by in situ measurements onboard the DLR research aircraft Falcon (Weinzierl, B., German Aerospace Centre DLR Oberpfaffenhofen, personal communication, 2010), respectively. We conclude that under favourable conditions laser-ceilometers may provide backscatter/extinction profiles of sufficient accuracy to infer rough estimates of the particle mass-concentrations with an uncertainty of about $15-50 \% /+100 \%$, provided co-located AOD and surface scattering coefficients as well as knowledge about the particle type are available. Referencing to lidar (preferentially Raman lidar) systems may allow transferring the calibration of backscatter/extinction profiles to other network ceilometers as well. Though errors of this magnitude may often be sufficient to decide whether ambient particle mass concentrations are potentially 20 dangerous for air traffic (present legal security threshold is $2 \mathrm{mg} / \mathrm{m}^{3}$ ) or not, ceilometers should be integrated with lidar networks into WMO's GALION to enable extrapolation of their more accurate profiles to contry-wide backscatter/extinction or mass distributions and fill temporal gaps.

\section{Conclusions}

Based on several significant and in part quasi-regularly occurring aerosol episodes we demonstrated the information content and potential applications of up-to-date ceilometers combined within the German Meteorological Service's synoptic observation net3657
AMTD

3, 3643-3673, 2010

DWD ceilometer network

H. Flentje et al.

\section{Title Page}

Abstract Introduction

Conclusions

References

Tables

Figures

I

14

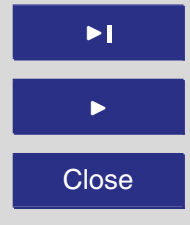

Back

Full Screen / Esc

Printer-friendly Version

Interactive Discussion

(i) 
work. More than 50 such instruments will finally be distributed all over Germany and allow not only for tracking the transport of desert dust, fire smoke, pollen and volcanic ash but also to estimate bulk optical and micro-physical properties of such aerosol plumes. The extinction coefficient and even the particle mass concentration may be 5 roughly estimated with however large uncertainties of $50 \%$ and $-50 \% /+100 \%$, respectively, provided co-located AOD measurements and (for mass) additional particle information are available. Their complementation with independent remote and in situ measurements - aircraft-borne or scattering sondes (Rosen and Kjome, 1991), particularly in case of overcast sky - is necessary for deriving further particle information. Mass 10 concentration estimates inferred for the Icelandic Eyjafjöll volcano ash-plume over Germany (about 500-750 $( \pm 300) \mu \mathrm{g} / \mathrm{m}^{3}$ on 17 April 2010 and about $30-50( \pm 20) \mu \mathrm{g} / \mathrm{m}^{3}$ on 19 April 2010) were in reasonable agreement with independent lidar and in situ measurements. Given these capabilities and keeping in mind the limitations, the backscatter/extinction profiles may be used to evaluate and improve vertical aerosol disributions

15 in both chemistry transport and meteorological models. With this, significant benefits for radiation and cloud condensation schemes can be expected.

Acknowledgements. We thank our colleagues from the DWD technical infrastructure department for the exhaustive by-hand collection and storage of the raw data from the synoptic network ceilometers during the Eyjafjoll eruption period.

\section{References}

Althausen, D., Engelmann, R., Baars, H., Heese, B., Ansmann, A., Müller, D., and Komppula, M.: Portable Raman Lidar Polly ${ }^{X T}$ for Automated Profiling of Aerosol Backscatter, Extinction, and Depolarization, J. Atmos. Oceanic Technol., 26, 2366-2378, 2009. 3655

Andreae, M. and Merlet, P.: Emissions of trace gases and aerosols from biomass burning, 25

Andreae, M. and Rosenfeld, D.: Aerosol-cloud-precipitation interactions, Part 1.: The nature and sources of cloud-active aerosols, Earth-Sci. Rev., 89, 13-41, 2008. 3645 
Ansmann, A., Riebesell, M., and Weitkamp, C.: Measurement of atmospheric aerosol extinction profiles with a Raman lidar, Opt. Lett., 15, 746-748, 1990. 3655

Ansmann, A., Tesche, M., Gross, S., Freudenthaler, V., Seifert, P., Hiebsch, A., Schmidt, J., Wandinger, U., Mattis, I., Müller, D., and Wiegner, M.: The 16 April 2010 major volcanic ash plume over Central Europe: EARLINET lidar and AERONET photometer observations at Leipzig and Munich, Germany, Geophys. Res. Lett., 37, L13810, doi: 10.1029/2010GL043809, 2010. 3657

Beyrich, F., Bange, J., Braam, M., Görsdorf, U., Hartogensis, O., and Martin, S.: Cross validation of boundary-layer parameters from in situ measurements and ground-based remote 10 sensing, ISARS, 2010. 3648

Böckman, C., Wandinger, U., Ansmann, A., Bösenberg, J., et al.: Aerosol lidar intercomparison in the framework of the EARLINET project. 2, Aerosol Backscatter Algorithms, Appl. Optics, 43, 977-989, 2004. 3645, 3647

Davis, K., Gamage, N., Hagelberg, C., Kiemle, C., Lenschow, D. H., and Sullivan, P.: An ob15 jective method for deriving atmospheric structure from airborne lidar observations, J. Atmos. Oceanic Tech., 17, 1455-1468, 2000. 3646

Dockery, D. and Stone, P.: Cardiovascular risks from fine particulate air pollution, New Engl. J. Med., 356, 511-513, 2007. 3645

Doherty, S., Anderson, T., and Charlson, R.: Measurement of the lidar ration for atmospheric aerosols with a $180^{\circ}$ backscatter nephelometer, Appl. Optics, 38, 1823-1832, 1999. 3653

Fernald, F. G.: Analysis of atmospheric lidar observations: some comments, Appl. Optics, 23, 652-653, 1984. 3647

Flentje, H., Werner, A., Claude, H., Gilge, S., Plass-Dülmer, C., Steinbrecht, W., Thomas, W., and Fricke, W.: Eyjafjallajkull ash plume - observations by DWD ceilometers, ozone sondes and in situ instruments, EGU General Assembly, Vienna, 3-7 May, 2010a. 3650

Flentje, H., Claude, H., Elste, T., Gilge, S., Köhler, U., Plass-Dlmer, C., Steinbrecht, W., Thomas, W., Werner, A., and Fricke, W.: The Eyjafjallajkull eruption in April 2010 detection of volcanic plume using in-situ measurements, ozone sondes and a new generation ceilometer network, Atmos. Chem. Phys. Discuss., 10, 14947-14968, doi:10.5194/acpd-1014947-2010, 2010. 3650, 3656

Forster, P., Ramaswamy, V., Artaxo, P., Berntsen, T., and Betts, R.: Changes in Atmospheric Constituents and in Radiative Forcing, in: Climate Change 2007: The Physical Science Basis. Contribution of Working Group I to the Fourth Assessment Report of the Intergovern-

\section{AMTD}

3, 3643-3673, 2010

\section{DWD ceilometer network}

H. Flentje et al.

\section{Title Page}

Abstract Introduction

Conclusions References

Tables Figures

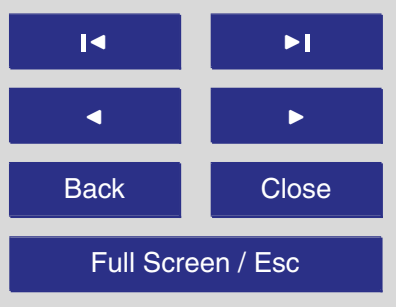

Printer-friendly Version

Interactive Discussion 
mental Panel on Climate Change, edited by: Solomon, S., Qin, D., Manning, M. Chen, Z., Marquis, M. et al., Cambridge University Press, Cambridge, United Kingdom 2007, available at: http://www.ipcc.ch, 2007. 3645

Frey, S., Poenitz, K., Teschke, G., and Wille, H.: Detection of aerosol layers with ceilometers and the recognition of the mixed layer depth, ISARS, 2010. 3646, 3647

Gerasopoulos, E., Kokkalis, P., Amiridis, V., Liakakou, E., Perez, C., Haustein, K., Eleftheratos, K., Andreae, M. O., Andreae, T., and Zerefos, C. S.: Dust specific extinction cross-sections over the Eastern Mediterranean using the BSC-DREAM model and sun photometer data: the case of urban environments, Ann. Geophys., 27, 2903-2912, 2009, http://www.ann-geophys.net/27/2903/2009/. 3652, 3656

Goode, J. G., Yokelson, R. J., Ward, D., Susott, R., Babbitt, R., Davies, M., and Hao, W.: Measurements of excess $\mathrm{O}_{3}, \mathrm{CO}, \mathrm{CO}_{2}, \mathrm{CH}_{4}, \mathrm{C}_{2} \mathrm{H}_{6}, \mathrm{C}_{2} \mathrm{H}_{6}, \mathrm{C}_{2} \mathrm{H}_{4}, \mathrm{HCN}, \mathrm{NO}, \mathrm{NH}_{3}, \mathrm{HCOOH}$, $\mathrm{CH}_{3} \mathrm{COOH}, \mathrm{HCHO}$ and $\mathrm{CH}_{3} \mathrm{OH}$ in 1997 Alaskan biomass burning plumes by airborne Fourier transform infrared spectroscopy (AFTIR), J. Geophys. Res., 105, 22147-22166, 2000. 3652

Gupta, P., A.Christopher, S., J.Wang, Gehrig, R., Lee, Y., and Kumar, N.: Satellite remote sensing of particulate matter and air quality assessment over global cities, J. Geophys. Res., 40, 5880-5892, 2006. 3656

Hansen, J., Sato, M., and Ruedy, R.: Radiative forcing and climate response, J. Geophys. Res., 102(D6), 6831-6864, 1997. 3645

20 Heese, B., Flentje, H., Althausen, D., and Ansmann, A.: Ceilometer Backscatter Coefficient Retrieval in the Boundary Layer - a Comparison to Raman Lidar Profiles, ISARS, 2010a. 3646

Heese, B., Flentje, H., Althausen, D., Ansmann, A., and Frey, S.: Ceilometer-Lidar InterComparision: Backscatter Coefficient Retrieval and Signal-to-Noise Ratio Determination, Atmos. Chem Phys. Discuss., in preparation, 2010b. 3646, 3649, 3655

Hess, M., Köpke, P., and Schult, I.: Optical properties of aerosols and clouds: The software package OPAC, Bull. Am. Met. Soc., 79, 831-844, 1998. 3653, 3656

Jäger, H. and Hoffmann, D.: Midlatitude lidar backscatter to mass, area, and extinction conversion model based on in situ aerosol measurements from 1980 to 1987, Appl. Optics, 30, 127-137, 1991. 3649, 3656

Kärcher, B.: Cirrus clouds in the tropical tropopause layer: Role of heterogeneous ice nuclei, Geophys. Res. Lett, 31, L12 101, doi:10.1029/2004GL019774, 2004. 3645

Klett, J. D.: Stable analytical inversion solution for processing lidar returns, Appl. Optics, 20,
AMTD

3, 3643-3673, 2010

DWD ceilometer network

H. Flentje et al.

\section{Title Page}

Abstract Introduction

Conclusions References

Tables Figures

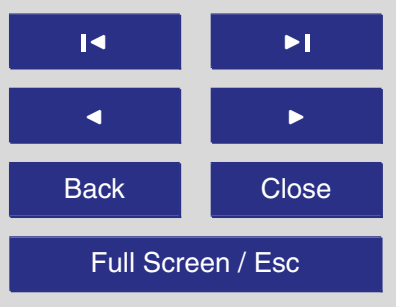

Printer-friendly Version

Interactive Discussion 
Klett, J. D.: Lidar inversion with variable backscatter/extinction ratios, Appl. Optics, 24, 16381643, 1985. 3647

Lacis, A. A. and Mishchenko, M. I.: Climate forcing, climate sensitivity and climate response: A 5 radiative modeling perspective on atmospheric aerosols., Aerosol forcing of climate, edited by: Charlson, R. J. and Heintzenberg J., J. Wiley and Sons, 416 pp., 1994. 3652

Matthias, V., Freudenthaler, V., Amodeo, A., Balin, I., Balis, D., Bösenberg, J., Chaikovsky, A., Chourdakis, G., Comeron, A., Delaval, A., Tomasi, F. D., Eixmann, R., Hgrd, A., Komguem, L., Kreipl, S., Matthey, R., Rizi, V., nio Rodrigues, J. A., Wandinger, U., and Wang, X.: Aerosol lidar intercomparison in the framework of the EARLINET project, 1. Instruments, Appl. Optics, 43, 961-976, 2004. 3645, 3647

Mattis, I., Ansmann, A., Mller, D., Wandinger, U., and Althausen, D.: Multiyear aerosol observations with dual-wavelength Raman lidar in the framework of EARLINET, J. Geophys. Res., 109, D13203, doi:10:1029/2004JD004600, 2004. 3647

15 Menut, L., Flamant, C., Pelon, J., and Flamant, P.: Urban Boundary-layer height determination from lidar measurements over the Paris Area, Appl. Optics, 109, 945-954, doi:10:1029/ 2004JD004600, 1999. 3646

Müller, D., Ansmann, A., Mattis, I., Tesche, M., Wandinger, U., Althausen, D., and Pisani, G.: Aerosol-type-dependent lidar ratios observed with Raman lidar, J. Geophys. Res., 112,

20 D16 202, doi:10.1029/2006JD008292, 2007. 3647, 3655

Münkel, C., Eeresmaa, N., Räsänen, J., and Karppinen, A.: Retrieval of mixing height and dust concentration with lidar ceilometer, Bound.-Lay. Meteorol., 124, 117-128, 2007. 3646, 3648

Murayama, T., Sugimoto, N., Uno, I., Kinoshita, K., Aoki, K., Hagiwara, N., Liu, Z., Matsui, I., Sakai, T., Shibata, T., Arao, K., Sohn, B.-J., Won, J.-G., Yoon, S.-C., Li, T., Zhou, J., Hu, H., Abo, M., lokibe, K., Koga, R., and Iwasaka, Y.: Ground-based network observation of Asian dust events of 19 April 98 in east Asia, J. Geophys. Res., 106, 345-359, 2001. 3645

Papayannis, A., Amiridis, V., and Mona, L.: Systematic lidar observations of Saharan dust over Europe in the frame of EARLINET (2000-2002), J. Geophys. Res., 113, D10204, doi: 10.1029/2007JD009028, 2008. 3647, 3655

30 Pappalardo, G., Amadeo, A., and et al., M. P.: Aerosol lidar intercomparison in the framework of the EARLINET project. 3. Raman Lidar Algorithm for aerosol extinction, backscatter, and lidar ratio, Appl. Optics, 43(28), 5370-5385, 2004. 3645, 3647

Pappalardo, G., Amadeo, A., and Pandolfi, M.: Dispersion and evolution of the Eyjafjöljökull

AMTD

3, 3643-3673, 2010

DWD ceilometer network

H. Flentje et al.

\section{Title Page}

Abstract Introduction

Conclusions References

Tables Figures

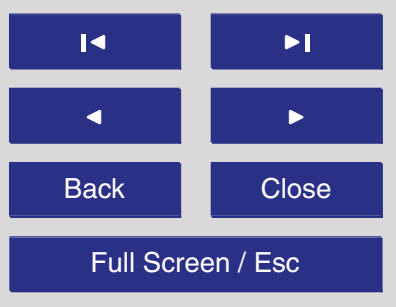

Printer-friendly Version

Interactive Discussion 
ash plume over Europe: vertically resolved measurements with the European LIDAR network EARLINET, EGU General Assembly, Vienna, 3-7 May, 2010. 3647, 3654, 3666

Peters, A., von Klot, S., Heier, M., Trentinaglia, I., Cyrys, J. G., and Pappalardo, G.: Particulate air pollution and nonfatal cardiac events. Part I: air pollution, personal activities, and onset 5 of myocardial infarction in a casecrossover study, HEI Research Report, 124, 1-82, 2005. 3645

Philipona, R., Behrens, K., and Ruckstuhl, C.: How declining aerosols and rising greenhouse gases forced rapid warming in Europe since the 1980s, Geophys. Res Lett., 36, L02 806, doi:10.1029/2008GL036350, 2009. 3645

10 Rauth, J.-C., Chazette, P., and Fortain, A.: New approach using lidar measurements to characterize spatiotemporal aerosol mass distribution in an underground railway station in Paris, Atmos. Environ., 43, 575-583, 2009. 3656

Rosen, J. and Kjome, T.: Backscattersonde: a new instrument for atmospheric aerosol research, Appl. Optics, 30, 12, 1552-1560, 1991. 3658

Stohl, A., Hittenberger, M., and Wottowa, G.: Validation of the Lagrangian particle dispersion model FLEXPART against large scale tracer experiments, Appl. Optics, 32, 24, 4245-4263, doi:1016/S1352-2310(98)00184-8, 1998. 3655

v. d. Hulst, H. C.: Light scattering by small particles, John Wiley \& Sons Inc., New York, USA, 470 pp., 1957. 3648

20 Wandinger, U., Müller, D., Böckmann, C., Althausen, D., Matthias, V., Bösenberg, J., Wei, V., Fiebig, M., Wendisch, M., Stohl, A., and Ansmann, A.: Optical and microphysical characterization of biomass burning and industrial-pollution aerosols from multiwavelength lidar and aircraft measurements, J. Geophys. Res., 107(D21), 8125, doi:10.1029/2000JD000202, 2002. 3652

Wang, J. and Christopher, S.: Intercomparison between satellite-derived aerosol optical thickness and PM2.5 mass: implications for air quality studies, Geophys. Res. Lett., 30, 2095, doi:10.1029/2003GRL018174, 2003. 3656

Wiegner, M.: Potential of ceilometers for aerosol remote sensing: a preliminary assessment, ILRC, 2010. 3646, 3649

30 WMO: Plan for the implementation of the Global Aerosol Lidar Observation Network GALION, WMO report, 178, 45 pp., 2007. 3645

\section{AMTD}

3, 3643-3673, 2010

DWD ceilometer network

H. Flentje et al.

\section{Title Page}

Abstract Introduction

Conclusions

References

Tables

Figures

14

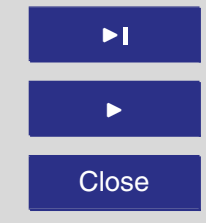

Back

Full Screen / Esc

Printer-friendly Version

Interactive Discussion 


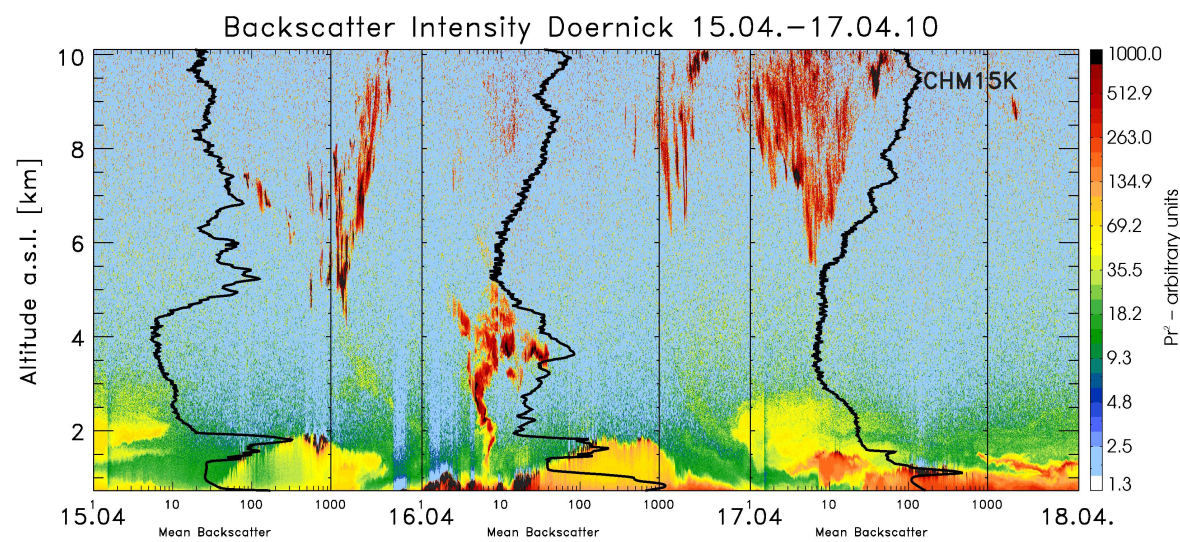

Fig. 1. Time-height section $(0-10 \mathrm{~km})$ of range-corrected backscatter at Doernick (NGermany), measured by ceilometer on 15-17 April 2010. Daily average backscatter profiles indicate the vertical distribubtion. The Eyjafjöll volcano ash (orange-red) moved over the site in $1-5 \mathrm{~km}$ altitude from the evening of 15 April till noon of 16 April. During part of the period, beam-blocking low clouds prevented the measurement. The signals above $5 \mathrm{~km}$ are clouds, as confirmed by a webcam.

\section{AMTD}

3, 3643-3673, 2010

\section{DWD ceilometer network}

H. Flentje et al.

\section{Title Page}

\section{Abstract}

Introduction

Conclusions

References

Tables

Figures

14

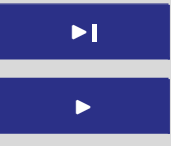

Back

Close

Full Screen / Esc

Printer-friendly Version

Interactive Discussion 


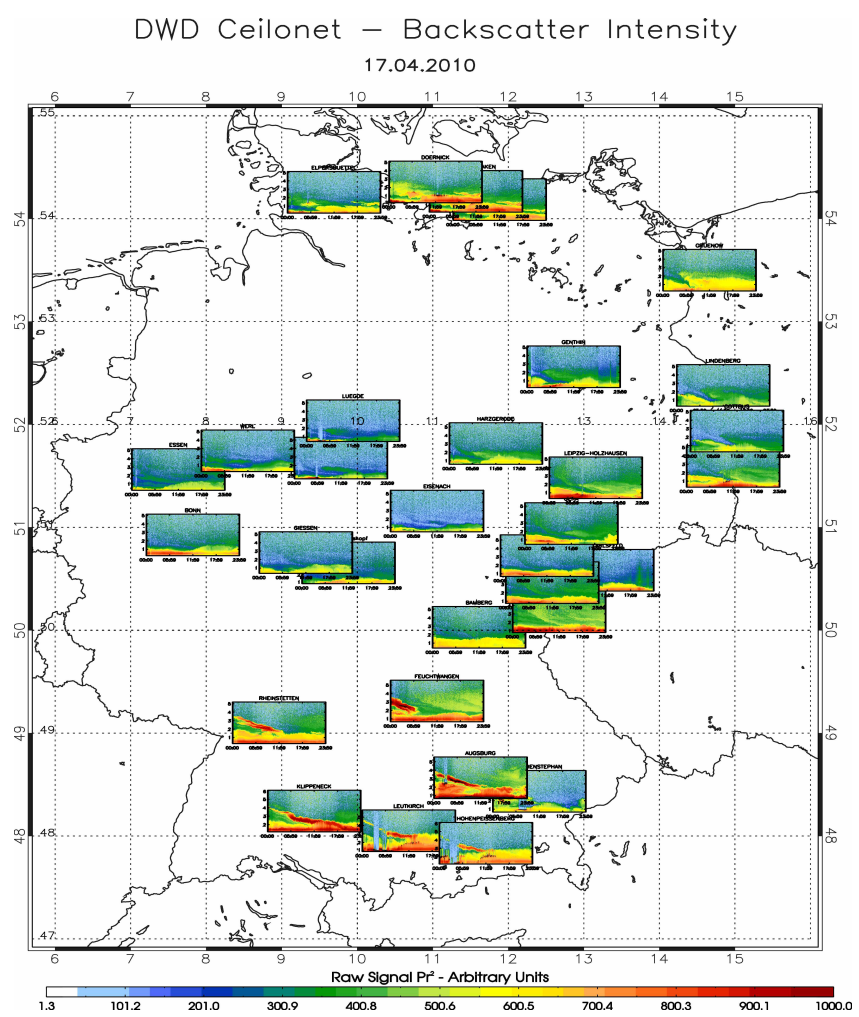

Fig. 2. Time-height sections $(0-5 \mathrm{~km})$ of range-corrected backscatter at the DWD ceilometer stations on arrival of the Eyjafjöll volcano ash on 17 April 2010. The ash-layer (yellow-orangered) arrived over south Germany, subsiding from about 5 to $2 \mathrm{~km}$ and was entrained into the boundary layer in the afternoon.
AMTD

3, 3643-3673, 2010

DWD ceilometer network

H. Flentje et al.

Title Page

\section{Abstract}

Introduction

Conclusions

References

Tables

Figures

14

$\rightarrow 1$
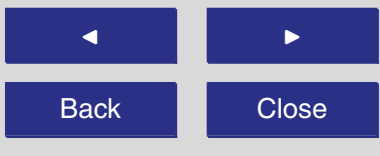

Full Screen / Esc

Printer-friendly Version

Interactive Discussion 

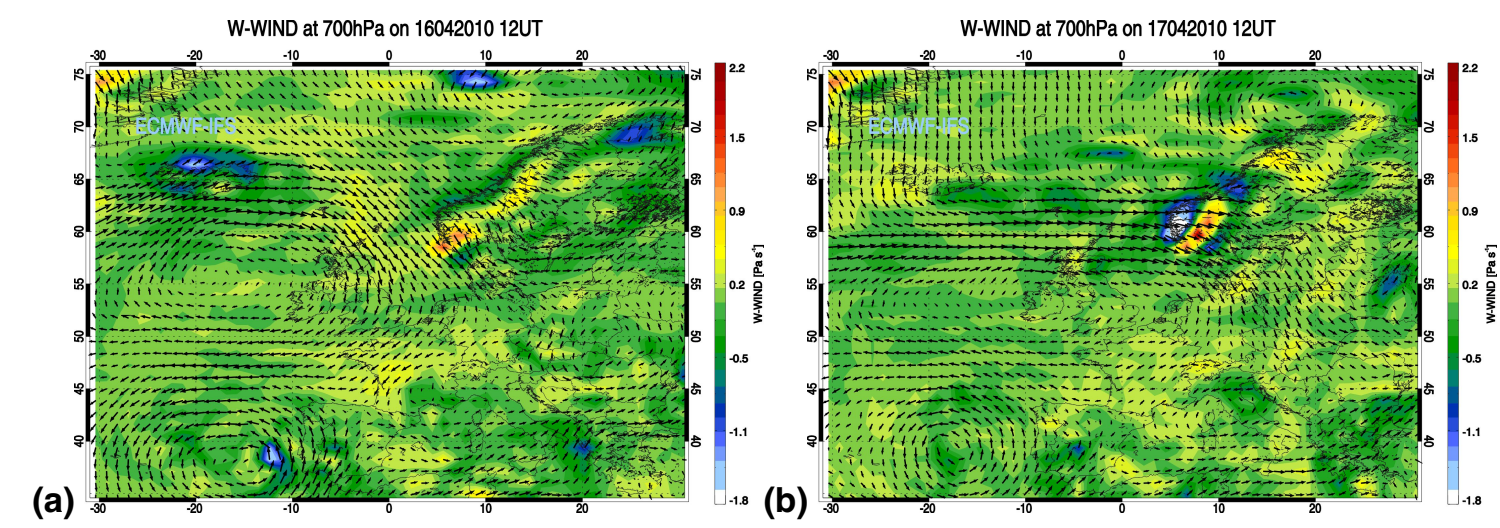

Fig. 3. ECMWF vertical wind and velocity vectors at $700 \mathrm{hPa}$ on 16 and 17 April 2010, 12:00 UTC, indicating subsidence over large parts of Germany during the traverse of the Eyjafjöll ash-cloud.

\section{AMTD}

\section{3, 3643-3673, 2010}

\section{DWD ceilometer network}

H. Flentje et al.

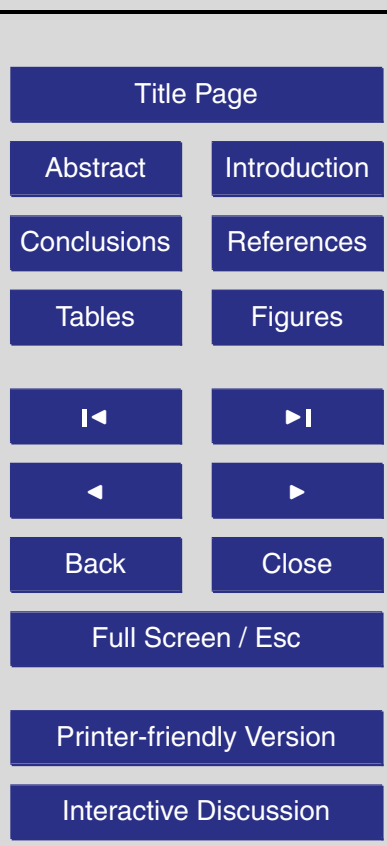

(9) (1) 


\section{AMTD}

3, 3643-3673, 2010

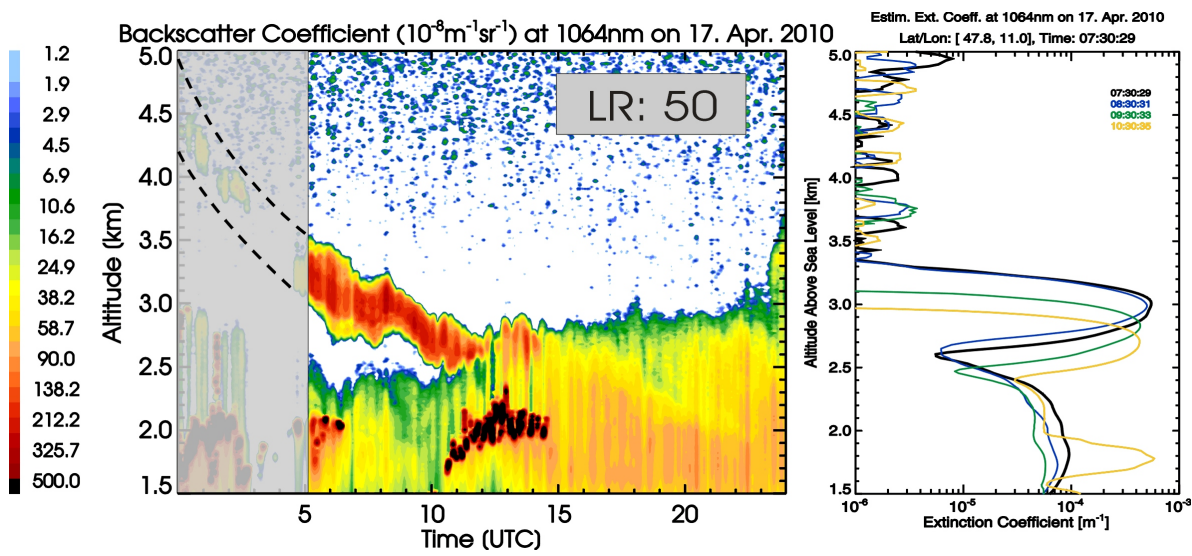

Estim. Ext. Coeft. at $1064 \mathrm{~nm}$ on 17 . Apr. 2010

LatLon: [ 47.8, 11.0], Time: 07:30:29

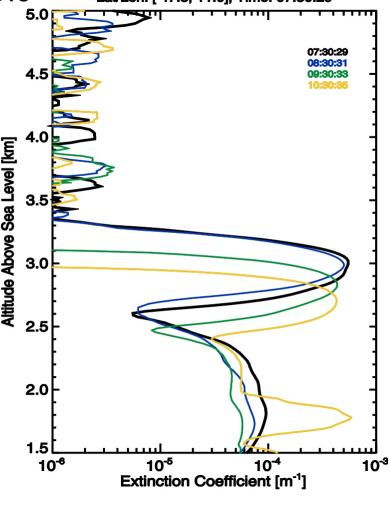

Fig. 4. Left: Backscatter Coefficient at Hohenpeissenberg $\left(47.8^{\circ} \mathrm{N}, 11.0^{\circ} \mathrm{E}\right)$ on 17 April 2010 , showing the subsidence of the Eyjafjöll ash layer and its entrainment into the PBL. Before about 06:00 UTC detection of the ash layer was prevented by low clouds. Right: Inferred extinction coefficient profiles, each averaged over 1 hour. An Inversion is possible after 05:00 UTC - a lidar ratio of 50 (Pappalardo et al., 2010) and BSR of 1.2 was assumed in $3.8-4.5 \mathrm{~km}$ for the whole day, yielding extinctions in agreement with AOD observations. The complete overlap of laser beam and telescope is only reached above $1.5 \mathrm{~km}$ altitude.

\section{DWD ceilometer network}

H. Flentje et al.

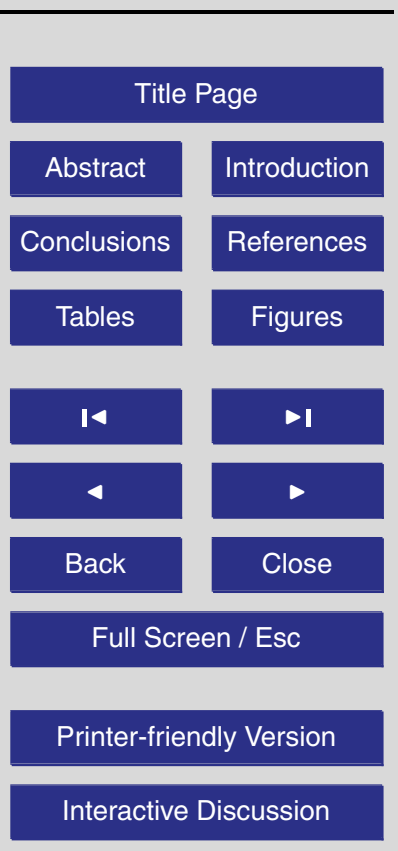




\section{AMTD}

\section{3, 3643-3673, 2010}

\section{DWD ceilometer network}

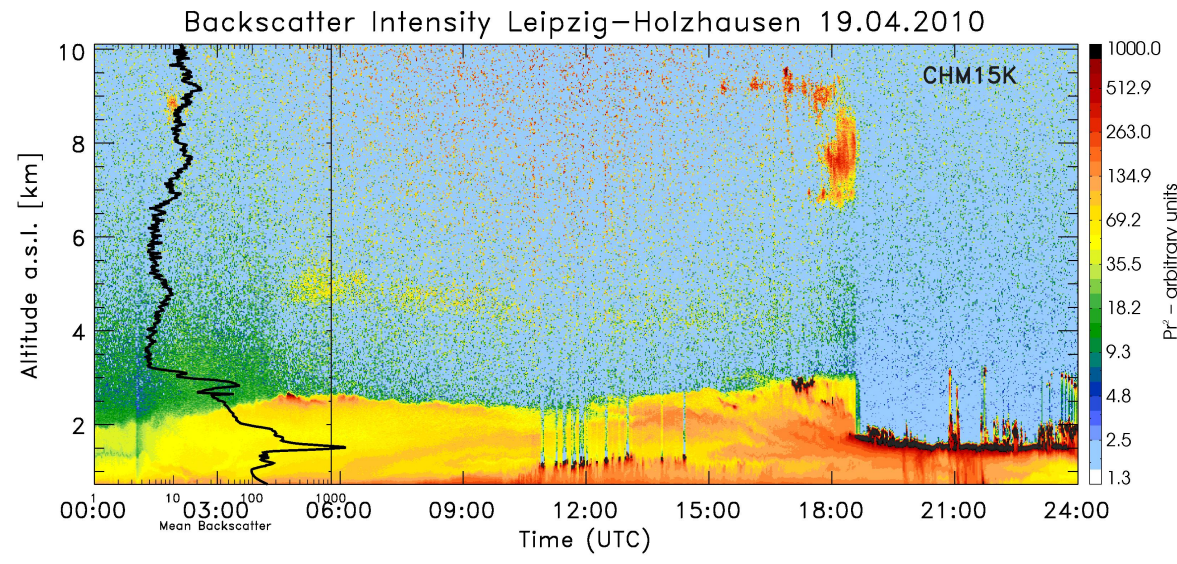

H. Flentje et al.

Title Page

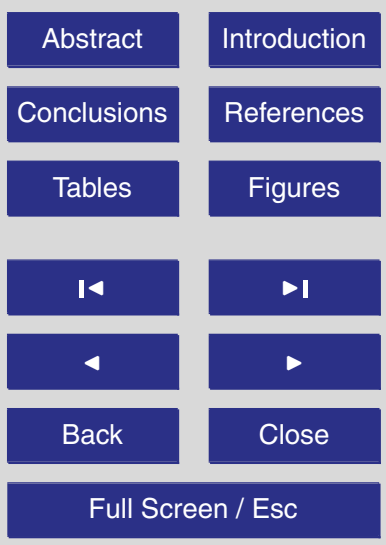

Fig. 5. Time-height section $(0-10 \mathrm{~km})$ of range-corrected backscatter at Leipzig-Holzhausen (Germany), measured by ceilometer on 19 April 2010. A daily average backscatter profile accentuates the Eyjafjöll ash-layer between 4 and $5.5 \mathrm{~km}$ altitude. From about 19:00 UTC onward low clouds block the laser beam. The signals above $7 \mathrm{~km}$ are clouds, as confirmed by a webcam.

Printer-friendly Version

Interactive Discussion 


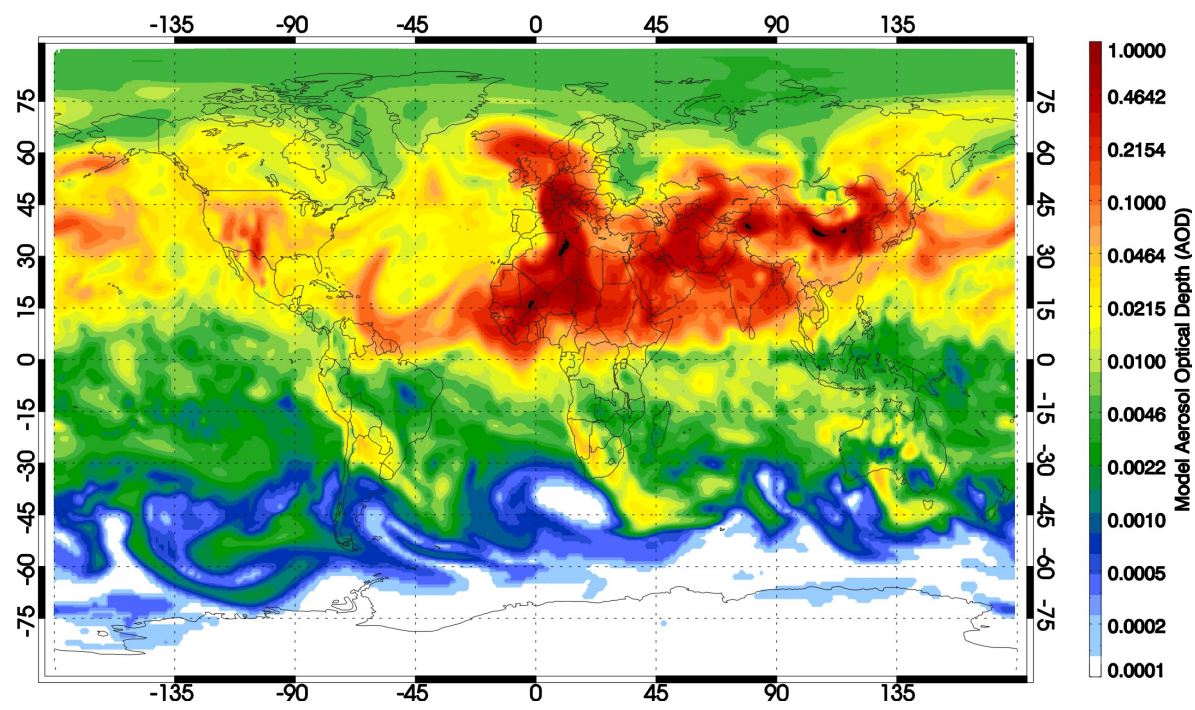

Fig. 6. Aerosol optical depth of desert dust particles on 29 May 2008, 00:00 UT, as analysed by the GEMS global model at the European Centre for Medium Range Weather Forecasts (ECMWF), available at: http://www.gmes-atmosphere.eu/d/services/gac/nrt/nrt_opticaldepth.

\section{AMTD}

3, 3643-3673, 2010

\section{DWD ceilometer network}

H. Flentje et al.

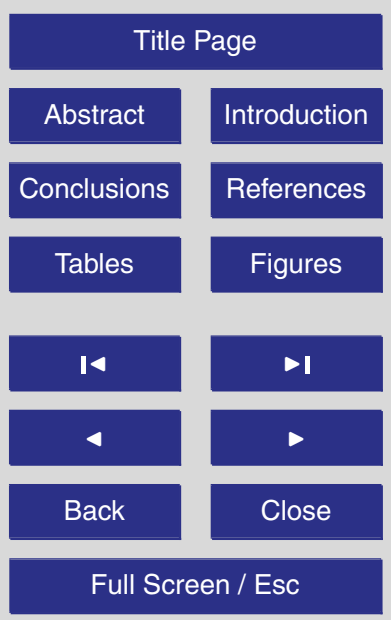

Printer-friendly Version

Interactive Discussion 


\section{AMTD}

\section{3, 3643-3673, 2010}

\section{DWD ceilometer network}

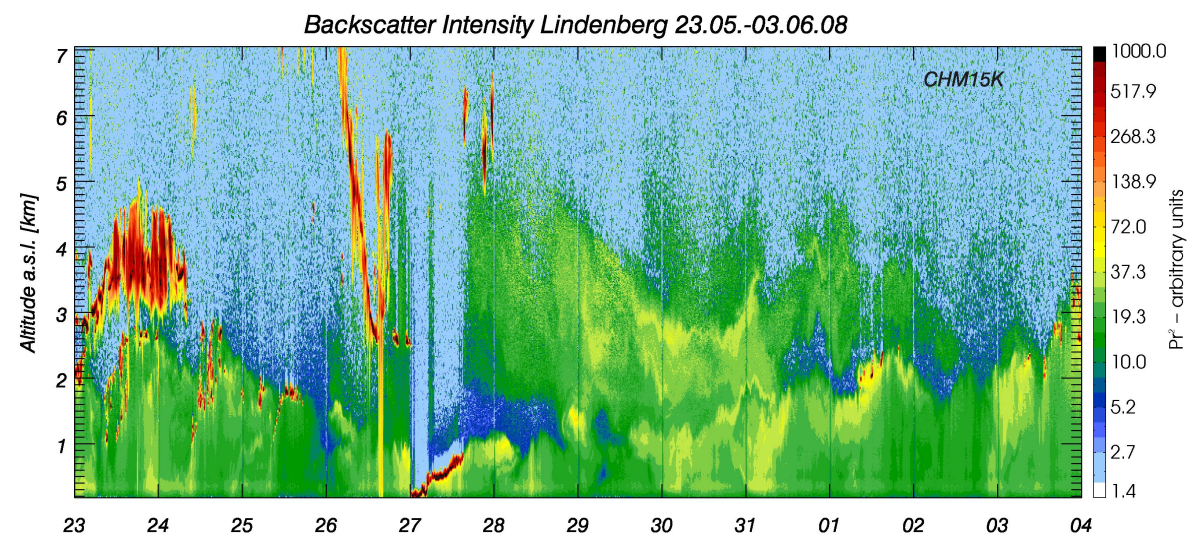

H. Flentje et al.

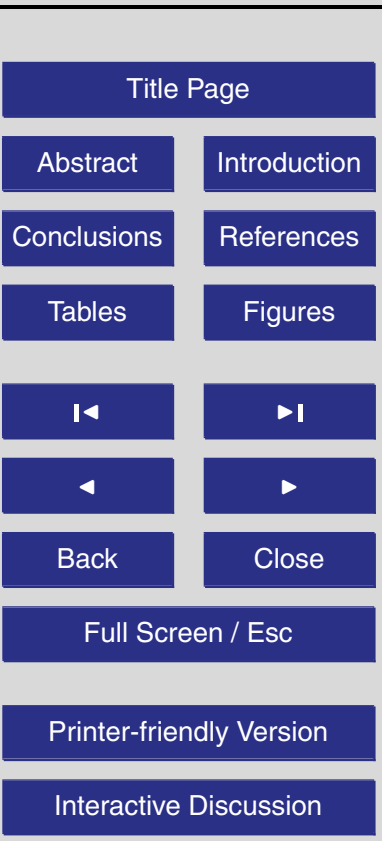

Fig. 7. Time-height section (0-7 kma.s.l.) of range-corrected backscatter over Lindenberg/Germany showing Saharan dust up to $6 \mathrm{~km}$ (green-yellow plume) measured by a CHM15K ceilometer from 23 May-3 June 2008. 
AMTD

3, 3643-3673, 2010

DWD Ceilonet - Backscatter Intensity

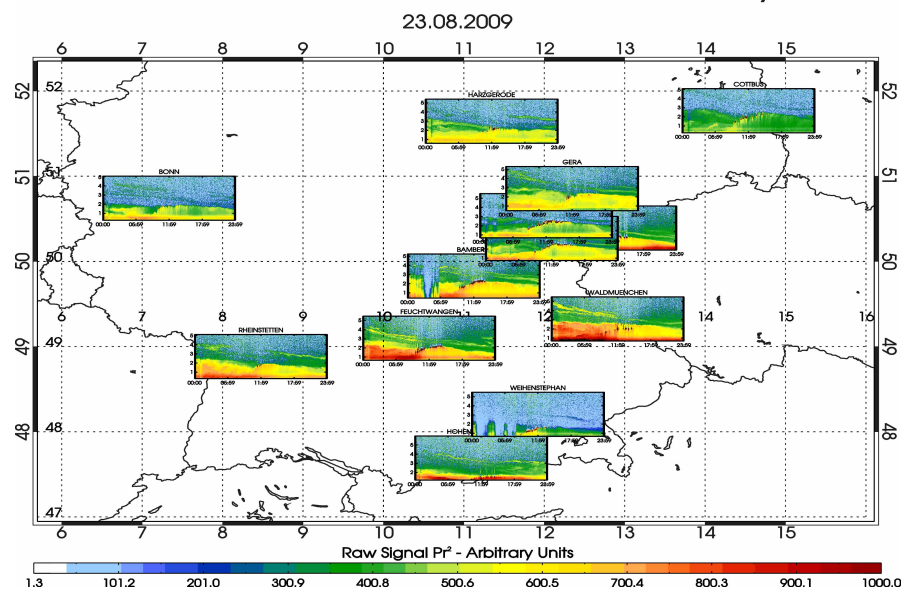

Fig. 8. Time-height sections of range-corrected backscatter at the DWD ceilometer stations showing smoke layers (yellow-green) from Mediterranean fires above the PBL (yellow-orange) on 23 August 2009.

\section{DWD ceilometer network}

H. Flentje et al.

\section{Title Page}

\section{Abstract}

Introduction

Conclusions

References

Tables

Figures

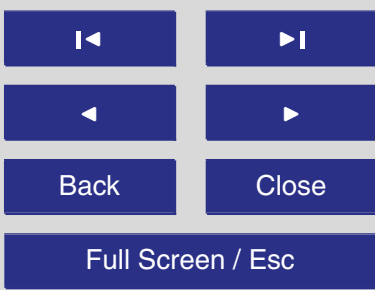

Printer-friendly Version

Interactive Discussion 


\section{AMTD}

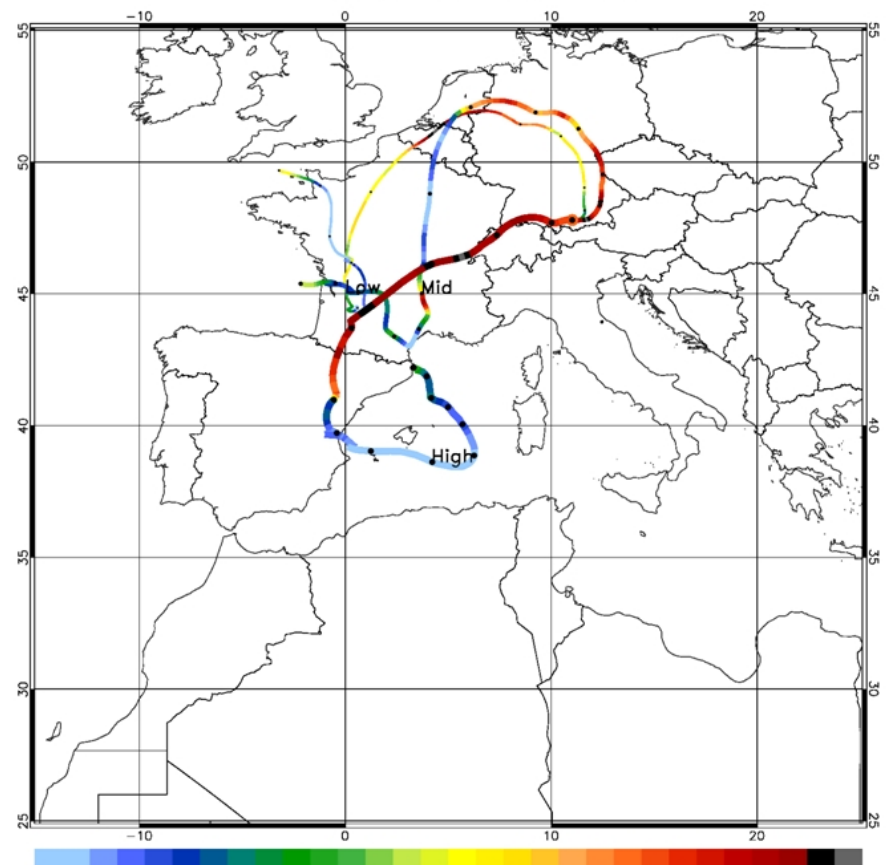

\section{3, 3643-3673, 2010}

\section{DWD ceilometer network}

H. Flentje et al.

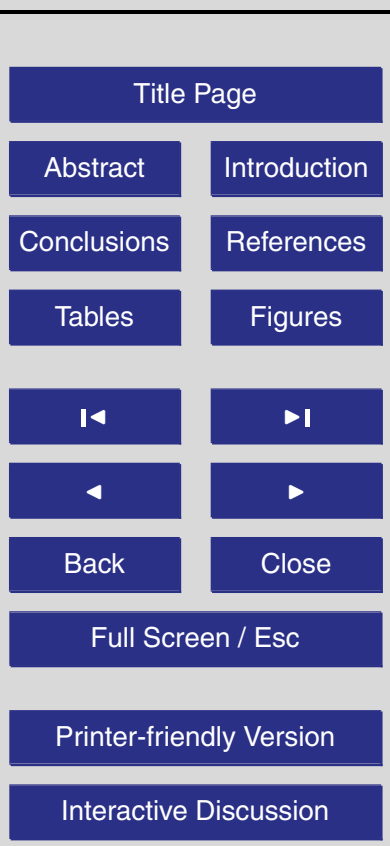

Fig. 9. 7-day back-trajectories calculated by the DWD Global Model ending at Hohenpeissenberg (South Germany) on 23 August 2009. Colour coded is the altitude in ma.s.l. The air mass is tracked back to the Western Mediteranean region where the fires occurred. 


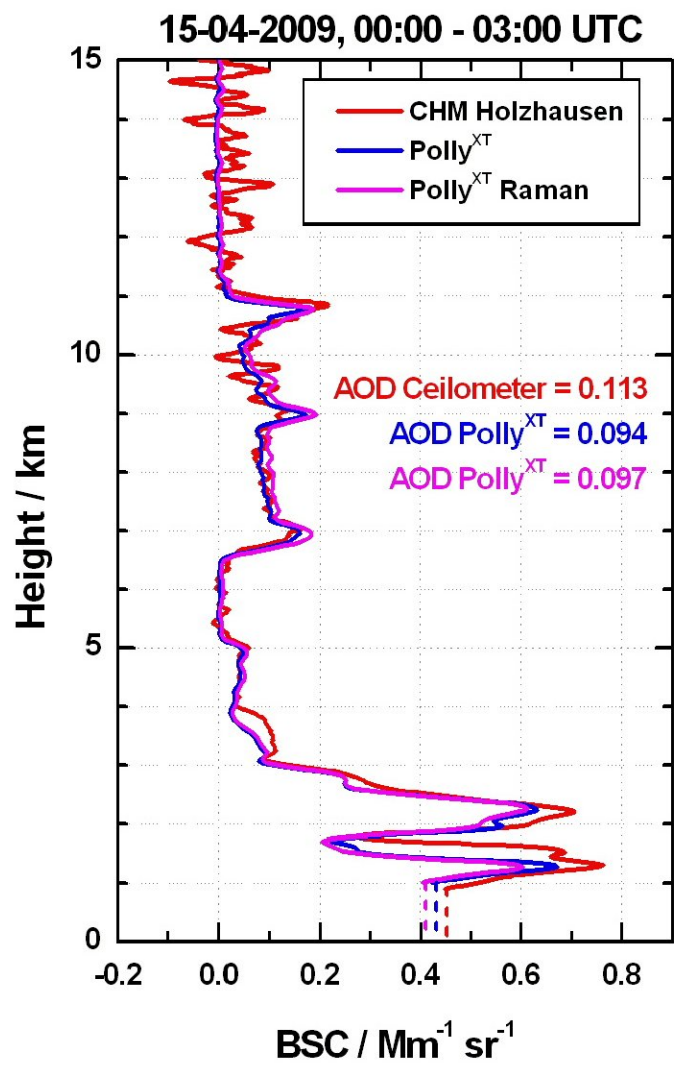

AMTD

3, 3643-3673, 2010

DWD ceilometer network

H. Flentje et al.

Title Page

Abstract

Introduction

Conclusions

References

Tables

Figures

I

4
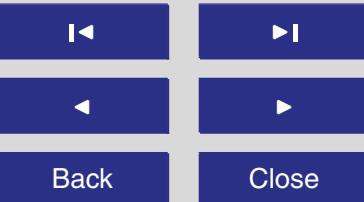

Full Screen / Esc

Printer-friendly Version

Interactive Discussion Holzhausen/Germany with Polly ${ }^{X T}$ Raman lidar at IfT Leipzig/Germany, about $2 \mathrm{~km}$ apart, on 15 April 2009. In red the ceilometer profile, in blue and pink the elastic and inelastic (Raman) lidar profiles, respectively. 
AMTD

3, 3643-3673, 2010

Specific Extinction Coefficient @ 1064 nm

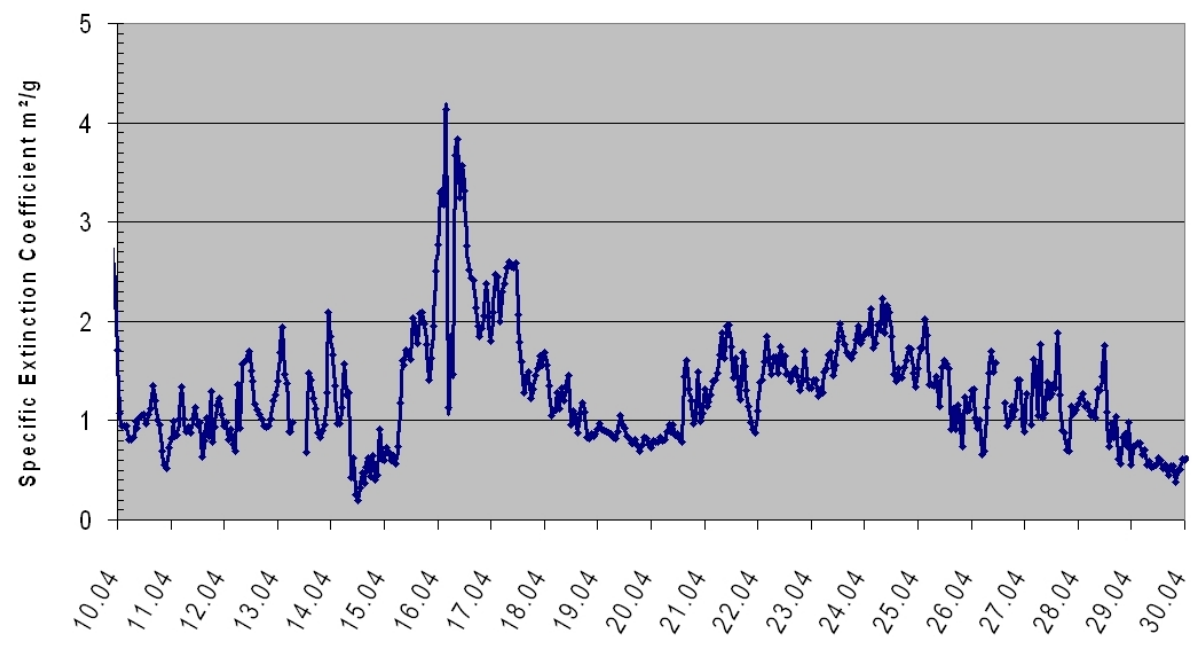

Fig. 11. Specific scattering ( $\approx$ specific extinction) coefficient at Hohenpeissenberg before and during the Eyjafjöll eruption in April 2010, calculated from surface nepehlometer and particulate mass-concentration $\left(\mathrm{PM}_{10}\right)$ measurements. The main body of the ash was observed near the surface on 18 to 20 April 2010.

\section{DWD ceilometer network}

H. Flentje et al.

\section{Title Page}

\section{Abstract}

Introduction

Conclusions

References

Tables

Figures

14

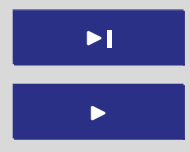

Back

Close

Full Screen / Esc

Printer-friendly Version

Interactive Discussion 